\title{
OCCURRENCE AND IMPACT OF INSECTS IN MAXIMUM GROWTH PLANTATIONS
}

\author{
FINAL REPORT
}

By:

John T. Nowak ${ }^{1}$ and C. Wayne Berisford ${ }^{2}$

To:

USDA Forest Service

Forest Health Protection

Atlanta, GA 30309

1. USDA Forest Service, Forest Health Protection, Pineville, LA 71360

2. Department of Entomology, University of Georgia, Athens, GA 30602 


\begin{abstract}
Intensive forest management practices have been shown to increase tree growth and shorten rotation time. However, they may also increase the need for insect pest management because of higher infestation levels and lower action thresholds. To investigate the relationship between inensive management practices and insect infestation, maximum growth potential studies of loblolly pine, Pinus taeda L., were conducted over 5 yr using a hierarchy of cultural treatments. The treatments were herbaceous weed control $(\mathrm{H}), \mathrm{H}+$ irrigation $(\mathrm{I}), \mathrm{H}+\mathrm{I}$ fertilizer $(\mathrm{F})$, and $\mathrm{H}+$ $\mathrm{I}+\mathrm{F}+$ pest control $(\mathrm{P})$. These treatments were monitored for differences in growth and insect infestation levels related to the increasing management intensities. The Nantucket pine tip moth, (Rhyacionia frustrana [Comstock]), was consistently found infesting study trees. In the third field season, the $\mathrm{H}+\mathrm{I}+\mathrm{F}+\mathrm{P}$ treatment had signicantly more southern pine coneworm, Dioryctria amatella (Hulst), attacks than the $\mathrm{H}$ and $\mathrm{H}+\mathrm{I}$ treatments. There were significant differences in volume index $\left(\mathrm{D}^{2} \mathrm{H}\right)$ among all treatments after each of the five growing seasons. This study demonstrated that tree fertilization can increase coneworm infestation and demonstrated that tip moth management improves tree growth, at least initially. Future measurements will determine if the growth gains from tip moth management are transitory or sustainable.
\end{abstract}

\title{
INTRODUCTION
}

The demand for forest products in the United States is growing while the land base for producing these commodities is shrinking as a result of conversions to other uses, increased land fragmentation, and concerns about endangered species and old growth forests. In order to meet 
timber and fiber needs, commercial forests must be managed more efficiently. Intensive management practices, such as herbaceous weed control, irrigation, and fertilization can increase tree growth and shorten rotation time (Pritchett and Smith 1972, Haywood 1986, Zutter and others 1986, Creighton and others 1987). Unfortunately, they may also increase the frequency and severity of pest infestations (Hedden and Nebeker 1984, Ross and others 1990). There is a critical need for studies on the effects of intensive forest management practices on pest insect populations.

Loblolly pine (Pinus taeda L.) is the most commercially important tree species in the southeastern United States. Several insects are associated with young stands of loblolly pine and are likely to become more important as management intensity increases. The Nantucket pine tip moth (Rhyacionia frustrana [Comstock]), is one such species (Sun and others 1998). Feeding by tip moth larvae can decrease tree growth in the early years following stand establishment (Warren 1964, Beal 1967, Lashomb and others 1978, Berisford and others 1989). Tip moth infestation levels often vary with intensity of silvicultural manipulations, such as mechanical site preparation, herbaceous weed control, and fertilization (Hertel and Benjamin 1977, White and others 1984, Ross and Berisford 1990, Ross and others 1990). Miller and Stephen (1983) concluded that differences in vegetation levels were not a good indicator of tip moth damage. However, Ross and others (1990) found that herbicide-treated plots had signicantly more tip moth damage than control plots during the first two growing seasons of a study conducted on the upper Coastal Plain of Georgia. Pritchett and Smith (1972) showed significant reductions in tip moth damage levels related to phosphorus $(\mathrm{P})$ and potassium $(\mathrm{K})$ fertilization, but no differences were observed after nitrogen $(\mathrm{N})$ fertilization. 
In January 1995, International Paper Corporation established a study of loblolly pine at their Southlands Experimental Research Forest near Bainbridge, GA to determine the maximum growth potential of loblolly pine using several hierarchies of cultural treatments. We examined the pest problems associated with these intensively managed loblolly pine within the first five years following stand establishment. Our objectives were to monitor insect pest establishment and to quantify insect associated growth losses among the different silvicultural treatments.

\section{MATERIALS AND METHODS}

This study was conducted in Decatur County, GA, about $20 \mathrm{~km}$ south of Bainbridge. The soil type was classified as a Wagram-troup complex and the site index was estimated to be 59 (base age 25; loblolly pine) (Personal communication. Tom Cooksey, Southlands Experiment Forest, International Paper Corp., Bainbridge, GA, 31717). The main study area was established on an old agricultural field that had been used to grow soybeans and watermelon. The surrounding plant community included a mixture of agricultural crop lands, hardwood forests, and longleaf (Pinus palustris Mill.) and loblolly pine forests of varying age classes.

A randomized complete block design with three blocks of four treatments was established. Each treatment plot was 0.2 ha, and contained 216 1-0 seedlings (grown for one year in the nursery before being planted in the field) (12 rows of 18 seedlings) hand planted in January 1995. One row on the end of each plot was designated as a border row and excluded from subsequent evaluations of insect infestation. Four improved loblolly pine seed sources from a nursery in North Carolina were blocked randomly within each plot. The site was subsoiled on $4 \mathrm{~m}$ centers and harrowed two months prior to planting. Sulfometuron (Oust $(\mathbb{R})$ $(0.28 \mathrm{~kg}[\mathrm{AI}] / \mathrm{ha})$ herbicide was applied once prior to planting and glyphosphate (Accord® $1.8 \mathrm{~kg}$ 
$[\mathrm{AI}] /$ ha) was applied twice prior to planting and then monthly during the growing season throughout the study to minimize herbaceous weeds.

The treatments were herbaceous weed control $(\mathrm{H}), \mathrm{H}+$ irrigation $(\mathrm{I}), \mathrm{H}+\mathrm{I}+$ fertilization (F), and $\mathrm{H}+\mathrm{I}+\mathrm{F}+$ pest control $(\mathrm{P})$. In the original study design, the control treatment was the $\mathrm{H}$ treatment. However, because weed control has been shown to influence tip moth damage levels (Ross and others 1990), we included three additional control plots in a nearby stand that represented more typical forest management. The control stand (C), approximately 250 ha in size, was located $<1 \mathrm{~km}$ north of the main study site and contained 1-0 seedlings machine planted concurrently with the main study site. Except for a site preparation application of herbicides (Sulfometuron) and a prescribed burn prior to planting, competing vegetation was not managed in this stand. A number of factors besides weed control could contribute to differences between the control plots and the more intensively managed main study plots. However, we believe that these comparisons provide useful information regarding the potential differences between intensive cultural practices and traditional forest management.

A dripline irrigation and fertigation (water and nutrients) system (Netafim Irrigation, Altamonte Springs, FL) was used to add water and nutrients. Water was pumped directly from a nearby lake onto the treatments receiving irrigation on a nightly interval at a rate $0 f 18 \mathrm{~cm}$ per year. Nitrogen was applied to the treatments receiving fertilizer at rates of $45 \mathrm{~kg} / \mathrm{ha}$ in 1995, 79 $\mathrm{kg} / \mathrm{ha}$ in 1996, $133 \mathrm{~kg} / \mathrm{ha}$ in 1997 and $111 \mathrm{~kg} / \mathrm{ha}$ in 1998 using an 8-2-8 liquid fertilizer formulation. Fertilizer applications were distributed evenly from April through November. Permethrin (Pounce® 3.2 EC, FMC Corporation, Philadelphia, PA) $(1.1 \mathrm{~kg}[\mathrm{AI}] / 2.5 \mathrm{ha})$ and acephate (Orthene ${ }^{\circledR} 75$ Turf, Tree and Ornamental, Valent USA Corp.) (2.2 kg [AI]/78 liters) were applied separately with backpack sprayers (Solo $\AA$, Newport News, VA) to the $\mathrm{H}+\mathrm{I}+\mathrm{F}+\mathrm{P}$ 
treatment throughout each growing season at biweekly intervals in 1995-1997. Insecticide applications were discontinued for the first seven months of 1998, but were resumed in September. The insecticide treatments had been discontinued because of the large size of the trees and the lack of tip moth in the previous two years.

Nantucket pine tip moth damage was evaluated three times annually following the first, second, and combined third and fourth generations. The third and fourth generations were combined into one evaluation date because of considerable damage overlap between these two generations (Berisford and others 1992). Evaluation dates were timed to coincide with either the tip moth pupal stage or just after adult emergence (Ross and Berisford 1990). Forty trees per treatment per block were randomly selected on each evaluation date. All shoots were examined for tip moth damage during each evaluation in 1995-1997. However, due to the size of the trees in 1998, only the terminal and top 2 branch whorls were examined. There is a significant correlation between terminal and top whorl damage and whole tree damage (Fettig and Berisford 1999). In 1999, the trees were too large to reach the tops with a ladder, therefore shoots were randomly clipped from the top of the trees with pole pruners. Damage was recorded as the percentage of damaged shoots; a shoot was defined as an apical meristem containing at least 5 $\mathrm{cm}$ of foliage.

Coneworm damage was recorded for 40 sample trees per plot after damage was initially detected in September 1997. Each larval entrance hole was counted as one coneworm attack. Damage was reported as the number of attacks per stem and the worms were identified as southern pine coneworm, Dioryctria amatella (Hulst), by raring larvae excavated from the trees to adulthood.

Basal diameter and total height were measured following each growing season. For 
comparative purposes, a tree stem volume index was calculated by multiplying the square of the basal diameter times height $\left(\mathrm{D}^{2} \mathrm{H}\right)$. This volume index has been shown to correlate well with above-ground biomass (Hatchell and others 1985).

The control treatment means for insect damage were qualitatively compared to the combined means of the main study area because the control area was separate from the main study design. The growth data for the control site are included to illustrate the potential growth gains from intensive forestry. However, because factors other than weed control (i.e. site preparation and genetic source) could also have influenced insect damage levels and growth differences, statistical comparisons are not made between the main study site and the control site representing typical forest management. The data are included only to provide comparisons between typical forest management and intensive cultural practices for potential growth gains and implications for insect population dynamics.

Tip moth infestation percentages were arcsine square root transformed and subjected to an analysis of variance (ANOVA) by each evaluation date. The insect damage data are reported as the non-transformed means. Tree growth data were compared by ANOVA for each evaluation date. Insect damage and growth treatment data were analyzed as a randomized complete block design and means were separated using Proc GLM and Tukey's Studentized Range Test (SAS Institute 1988).

\section{RESULTS}

Tip moth damage levels exceeded 10 percent only twice during this study, in 1995, 1998, and 1999 (Fig. 1). Tip moth damage reached moderate levels in the third and fourth generation of 1995 and then dropped below 3 percent in 1996 and 1997 in the main study area. At the end 
of 1998 and 1999, tip moth damage was ca. 80 percent in the main study area. Damage in the control treatment never exceeded $35 \%$, even when damage was relatively high in the main study area.

No significant differences were detected in tip moth damage among the $\mathrm{H}, \mathrm{H}+\mathrm{I}$, and $\mathrm{H}+\mathrm{I}+\mathrm{F}$ treatments in any year $(P>0.05$; Tukey test $)$ and these treatments are combined for analysis (Fig. 1). Percent damage was significantly higher for these treatments than the $\mathrm{H}+\mathrm{I}+\mathrm{F}+\mathrm{P}$ treatment during the highest infestation periods (generations 3 \& 4 in October 1995 ( $F$ $=25.46$; d.f. $=3,6 ; P=0.0008)$ and October $1998(F=13.55$; d.f. $=3,6 ; P=0.0044))($ Fig. 1). However, at lower damage levels, no significant differences were found. Tip moth damage levels were noticeably higher in the main study area than in the control area during the periods of highest infestation (Fig. 1). There were no significant differences in tip moth damage levels among the four different seed sources used in the main study area $(P>0.05)$.

Southern pine coneworm larvae were first observed feeding in the main stems and terminals in 1997 . The $\mathrm{H}+\mathrm{I}+\mathrm{F}+\mathrm{P}$ treatment had significantly more trees attacked $(F=9.15$; d.f. $=3,6 ; P=0.0117)$ (Fig. 2A) and stem attacks per tree $(F=14.02$; d.f. $=3,6 ; P=0.0041)$ (Fig. 2B) than the $\mathrm{H}$, and $\mathrm{H}+\mathrm{I}$ treatments. Coneworm damage was not detected in the control plots. Significant differences were observed in height and volume among all treatments during 1995 and 1996 (Figs. 3 and 4). The $\mathrm{H}+\mathrm{I}+\mathrm{F}+\mathrm{P}$ treatment had significantly greater height and volume measurements than the other treatments at the end of 1995, 1996, 1998 and 1999. In 1997, there was no significant difference in height between the $\mathrm{H}+\mathrm{I}+\mathrm{F}$ treatment and the $\mathrm{H}+\mathrm{I}+\mathrm{F}+\mathrm{P}$ treatment (Fig. 3), but the $\mathrm{H}+\mathrm{I}+\mathrm{F}+\mathrm{P}$ treatment had a significantly greater volume index (Fig. 4). There was no significant difference in height between the $\mathrm{H}+\mathrm{I}$ and $\mathrm{H}+\mathrm{I}+\mathrm{F}$ treatments in 1998, but the $\mathrm{H}+\mathrm{I}+\mathrm{F}$ treatment had a significantly higher volume index (Fig. 4). The control 
treatment had the lowest values for height and volume measurements throughout the study (Figs. 3 and 4).

\section{DISCUSSION}

Tip moth damage in the Bainbridge study was at the highest level after the trees had exceeded what is normally considered susceptible size (Berisford 1988). Because of the absence of significant tip moth infestation after the 1995 growing season, it was thought that the trees in the more intensive treatments may have simply outgrown their susceptibility to attack in the first growing season. However, the high tip moth damage in 1998 and 1999 dispelled this hypothesis. It was thought that perhaps the pitch pine tip moth ( $R$. rigidana [Fernald]) was causing the infestation in 1998 because $R$. rigidana are more common in taller trees than $R$. frustrana (Berisford 1988). However, the moths were identified as R. frustrana based on Yates' (1967) key.

Tip moth infestation levels fluctuated more in the main study area without competing vegetation than in the control area with competing vegetation. Similar fluctuations were found by Miller and Stephen (1983), where tip moth damage levels fluctuated more in areas with low competing vegetation than in areas with high vegetation levels. Tip moth population levels in areas with competing vegetation appear to be more stable than populations in areas without competing vegetation. One possible reason for this could be that the tip moth natural enemy complex exerts a more consistent influence in areas with herbaceous weeds, perhaps because of a more favorable microclimate and the presence of food sources such as pollen and nectar (Pimentel 1961, Strong 1984). In a previous study, total parasitism was higher in areas with competing vegetation than in adjacent areas with significantly less vegetation (McCravy and 
Berisford In press). However, parasitism data were not collected in this study.

Irrigation and fertilization significantly increased tree growth, but did not affect tip moth infestation levels. In a greenhouse study, Ross and Berisford (1990) concluded that management practices that increase water and nutrient availability to loblolly pine increase the amount of tip moth infestation. Results of the fertilization treatments are consistent with other studies concerning the effects of fertilization on tip moth infestation levels (Pritchett and Smith 1972, Berisford and others 1989). However, none of these studies, including this one, accounted for the number of tip moth larvae or pupae per individual shoot. Ross and Berisford (1990) found that pupal densities were significantly higher in potted seedlings with high nutrient levels. More intensive studies are needed to investigate the effects of fertilization on the amount of tip moth attacks and subsequent infestation. If $\mathrm{N}$ fertilization increases tip moth infestation, it might not be economically feasible to apply fertilizer if growth gains were lost to insect infestation. On the other hand, it is possible that fertilization could be used to increase tree vigor and thereby reduce the impact of tip moth infestation.

Insecticide applications increased tree growth 27 percent over the $\mathrm{H}+\mathrm{I}+\mathrm{F}$ treatment even though tip moth infestations in the Bainbridge study were low compared to many other studies (Lashomb and others 1978, Miller and Stephen 1983, Ross and others 1990). In 1998, the insecticide applications were discontinued because of low insect infestation in the previous two years. The applications were resumed once heavy damage began to reappear in September of 1998. Therefore, tip moth infestation in the pest control plots was significantly lower than the other treatments, but could have been even lower if insecticide applications had been made in a manner consistent with previous years. It has been argued that growth losses due to tip moth infestation are transitory (Williston and Barras 1977); however, this was not evident in our five 
year study. Future growth measurements are intended. Longer-term studies have shown that growth increases due to tip moth management are maintained (Cade and Hedden 1987, Unpublished data. Wayne Berisford, Department of Entomology, University of Georgia, Athens, GA, 30602).

In conclusion, intensive forest management practices such as herbaceous weed control and $\mathrm{N}$ fertilization can in some cases exacerbate tip moth problems and may disrupt tip moth population dynamics. However, tip moth control can reduce grow losses associated with feeding damage.

\section{ACKNOWLEDGMENTS}

The author thanks Tom Cooksey (International Paper Corporation) for his assistance throughout this study. The author also thanks the following people for help in data collection and technical help: Chris Asaro, Anthony Coody, Charles Gasset, Richard Garland, Mitch Gibbs, Nick LeCroy, and Joe Petty (University of Georgia). The author is also grateful to International Paper Corporation and the Timber Company for providing access to research sites. Southern pine coneworm adults were identified by Jim Hanula, USDA Forest Service, Athens, GA. This research was supported in part by funds from the USDA Forest Service, Southern Research Station, and the University of Georgia Pine Tip Moth Research Consortium.

\section{REFERENCES}

Beal, R.H. 1967. Heavy tip moth attacks reduce early growth of loblolly and shortleaf pine.

USDA. Forest Service Research Note SO-54. New Orleans, LA: U.S. Department of Agriculture, Forest Service, Southern Forest Experiment Station. 
Berisford, C.W. 1988. The Nantucket pine tip moth. In Berryman, A.A.,ed. Dynamics of Forest Insects: patterns, causes, and implications. New York: Plenum Publishing Corporation: 141-161. Berisford, C.W.; Canalos, C.G.; Godbee, J.F. Jr.;Yates, H.O. III. 1992. Occurrence and seasonal activity of pine tip moths in Georgia. Georgia Forestry Research Paper No. 87. Macon, GA: Georgia Forestry Commission. $11 \mathrm{p}$.

Berisford, C.W.; Godbee, J.F. Jr.; Ross, D.W. 1989. Impact of pine tip moth control, weed control, and fertilizer on growth and form of loblolly pine. In Alfaro, R.I.; Golver, S.G. eds., Insects Affecting Reforestation: Biology and Damage. Proc. IUFRO Working Group, Insects Affecting Reforestation. Forestry Canada, Pacific Forestry Centre, Vancouver, BC, Canada: 130136.

Cade, S.C.; Hedden, R.L. 1987. Growth impact of pine tip moth on loblolly pine plantations in the Ouachita Mountains of Arkansas. Southern Journal of Applied Forestry. 11: 128-133.

Creighton, J.L.; Zutter, B.R.; Glover, G.R.; Gjerstad, D.H. 1987. Planted pine growth response to herbaceous vegetation control, treatment duration, and herbicide application technique. Southern Journal of Applied Forestry. 11: 223-227.

Fettig C.J.; Berisford, C.W. 1999. Nantucket pine tip moth phenology in eastern North Carolina and Virginia: implications for effective timing of insecticide applications. Southern Journal of Applied Forestry. 23: 30-38.

Hatchell, G.E.; Berry, C.R.; Muse, H.D. 1985. Nondestructive indicies related to above-ground above biomass of young loblolly and sand pines on ectomycorrhizal and fertilizer plots. Forest Science. 31: 419-427.

Haywood, J.D. 1986. Response of planted Pinus taeda L. to brush control in northern Louisiana. Forest Ecology and Management. 15: 129-134. 
Hedden, R.L.; Nebeker, T.E. 1984. Integrated pest management in pine stands (0-5 years) Insects. In Branham, S.J.;Hertel, G.D. eds., Proc., Intergrated Forest Pest Management Symposium. University of Georgia Center for Continuing Education, Athens, GA. 39-53

Hertel, G.D.; Benjamin, D.M. 1977. Intensity of site preparation influences on pine webworm and tip moth infestations of pine seedlings in North-central Florida. Environmental Entomology. 6: $118-122$.

Lashomb, J.H.; Steinhauer, A.L.; Douglass, L. 1978. Impact studies of Nantucket pine tip moth populations on loblolly pine. Environmental Entomology. 7: 910-912.

Miller, F.D., Jr.; Stephen, F.M. 1983. Effects of competing vegetation on Nantucket pine tip moth (Lepidoptera: Tortricidae) populations in loblolly pine plantations in Arkansas.

Environmental Entomology. 12: 101-105.

McCravy, K.W.; Berisford, C.W. [In press]. Effects of vegetation control on parasitoids of the Nantucket pine tip moth, Rhyacionia frustrana (Lepidoptera: Tortricidae). Florida Entomologist. Pimentel, D. 1961. Species diversity and insect population outbreaks. Annals of Entomological Society of America. 54: 76-86.

Pritchett, W.L.; Smith, W.H. 1972. Fertilizer responses in young pine plantations. Soil Science Society of America Proceedings 36: 660-663.

Ross, D.W.; Berisford, C.W. 1990. Nantucket pine tip moth (Lepidoptera: Tortricidae) response to water and nutrient status of loblolly pine. Forest Science. 36: 719-733.

Ross, D.W.; Berisford, C.W.; Godbee, J.F. Jr. 1990. Pine tip moth, Rhyacionia spp., response to herbaceous vegetation control in an intensively site-prepared loblolly pine plantation. Forest Science. 36: 1105-1118.

SAS Institute, Inc. 1988. SAS/STAT guide for personal computers, Version 6.03 ed. SAS 
Institute, Inc., Cary, NC. 1028 p.

Strong, D.R. 1984. Banana's best friend. Natural History. 93: 50-57.

Sun, J.; Kulhavy, D.L.; Yan, S. 1998. Prediction models of Nantucket pine tip moth, Rhyacionia frustrana (Comstock) (Lepidoptera: Tortricidae) infestation using soil and tree factors. Journal of Applied Entomology. 122: 1-3.

Warren, L.O. 1964. Growth of pine trees protected from attack by Nantucket pine tip moth. Arkansas Agricultural Research Station, Arkansas Farm Research 13: 11.

White, M.N.; Kulhavy, D.L.; Conner, R.N. 1984. Nantucket pine tip moth (Lepidoptera: Tortricidae) infestation rates related to site and stand characteristics in Nacogdoches county Texas. Environmental Entomology 13: 1598-1601.

Williston, H.L.; Barras, S.J. 1977. Impact of tip moth injury on growth and yield of 16-yr-old loblolly and shortleaf pine. USDA Forest Service Research Note SO-221. New Orleans, LA: U.S. Department of Agriculture, Forest Service, Southern Forest Experiment Station. 5 p.

Yates, H.O. III. 1967. Pupae of Rhyacionia frustrana, R. rigidana, and R. subtropica (Lepidoptera: Olethreutidae). Annals of Entomological Society of America. 60: 1096-1099. Zutter, B.R.; Glover, G.R.; Gjerstad, D.H. 1986. Effects of herbaceous weed control using herbicides on a young loblolly pine plantation. Forest Science. 32: 882-899.

\section{FIGURE CAPTIONS}

Fig. 1. Mean percent (+/-SE) of loblolly pine shoots damaged by Nantucket pine tip moth during 1995-1999 in Bainbridge, GA. Three treatments means [herbicide (H), $\mathrm{H}+$ irrigation (I), and $\mathrm{H}$ $+\mathrm{I}+$ fertilizer (F)] are classified as the Main Study Area for simplicity and the lack statistical differences $(P>0.05$; Tukey test). Bars with the same letter for each sample date are not 
significantly different $(\mathrm{n}=480 ; P>0.05$; Tukey test). Control means $(\mathrm{n}=120)$ are provided for comparative purposes only and are not included in the statistical analysis.

Fig. 2. Mean percent (+/-SE) of trees attacked (A) and mean number (+/-SE) of attacks per tree (B) by Southern pine coneworm on loblolly pine in the third growing season after various cultural treatments: Herbicide $(\mathrm{H}), \mathrm{H}+$ irrigation $(\mathrm{I}), \mathrm{H}+\mathrm{I}+$ fertilizer $(\mathrm{F})$, and $\mathrm{H}+\mathrm{I}+\mathrm{F}+$ pest control $(\mathrm{P})$. Bars with the same letter are not significantly different $(\mathrm{n}=480 ; P>0.05$; Tukey test). Control means $(n=120)$ are provided for comparative purposes only and are not included in the statistical analysis.

Fig. 3. Mean tree height ( $+/-\mathrm{SE})$ for five growing seasons in a study conducted in Bainbridge, GA, following yearly cultural treatments: Herbicide $(H), H+$ irrigation $(\mathrm{I}), \mathrm{H}+\mathrm{I}+$ fertilizer $(\mathrm{F})$, and $\mathrm{H}+\mathrm{I}+\mathrm{F}+$ pest control $(\mathrm{P})$. Bars with the same letter are not significantly different $(\mathrm{n}=$ 480; $P>0.05$; Tukey test). Control means $(\mathrm{n}=120)$ are provided for comparative purposes only and are not included in the statistical analysis.

Fig. 4. Mean tree volume index (+/-SE) (basal diameter-squared times height) for five growing seasons in a study in Bainbridge, GA following yearly cultural treatments: Herbicide $(\mathrm{H}), \mathrm{H}+$ irrigation (I), $\mathrm{H}+\mathrm{I}+$ fertilizer $(\mathrm{F})$, and $\mathrm{H}+\mathrm{I}+\mathrm{F}+$ pest control $(\mathrm{P})$. Bars with the same letter are not significantly different $(\mathrm{n}=480 ; P>0.05$; Tukey test). Control means $(\mathrm{n}=120)$ are provided for comparative purposes only and are not included in the statistical analysis.

Fig. 4. Mean percent (+/-SE) of loblolly pine shoots damaged by Nantucket pine tip moth during 
the third tip moth generation of 1999 in a study in Powelton, GA following cultural treatments: control, $\mathrm{N}$ fertilization ( $\mathrm{N}$-fert), herbicide (Herb), and herbicide application and $\mathrm{N}$ fertilization $($ Herb-N). Bars with the same letter for each sample date are not significantly different $(n=240$; $P>0.05$; Tukey test).

Fig. 5. Mean number of tip moth pupae per shoot $(+/-\mathrm{SE})$ for the third tip moth generation in a study conducted in Powelton, GA, following cultural treatments: control, $\mathrm{N}$ fertilization ( $\mathrm{N}$-fert), herbicide (Herb), and herbicide application and $\mathrm{N}$ fertilization (Herb-N). Bars with the same letter are not significantly different $(\mathrm{n}=300 ; P>0.05$; Tukey test).

Fig. 6. Mean tree diameter (+/-SE) for the third tip moth generation in a study conducted in Powelton, GA, following cultural treatments: control, $\mathrm{N}$ fertilization ( $\mathrm{N}$-fert), herbicide (Herb), and herbicide application and $\mathrm{N}$ fertilization (Herb-N). Bars with the same letter are not significantly different $(\mathrm{n}=240 ; P>0.05$; Tukey test). 


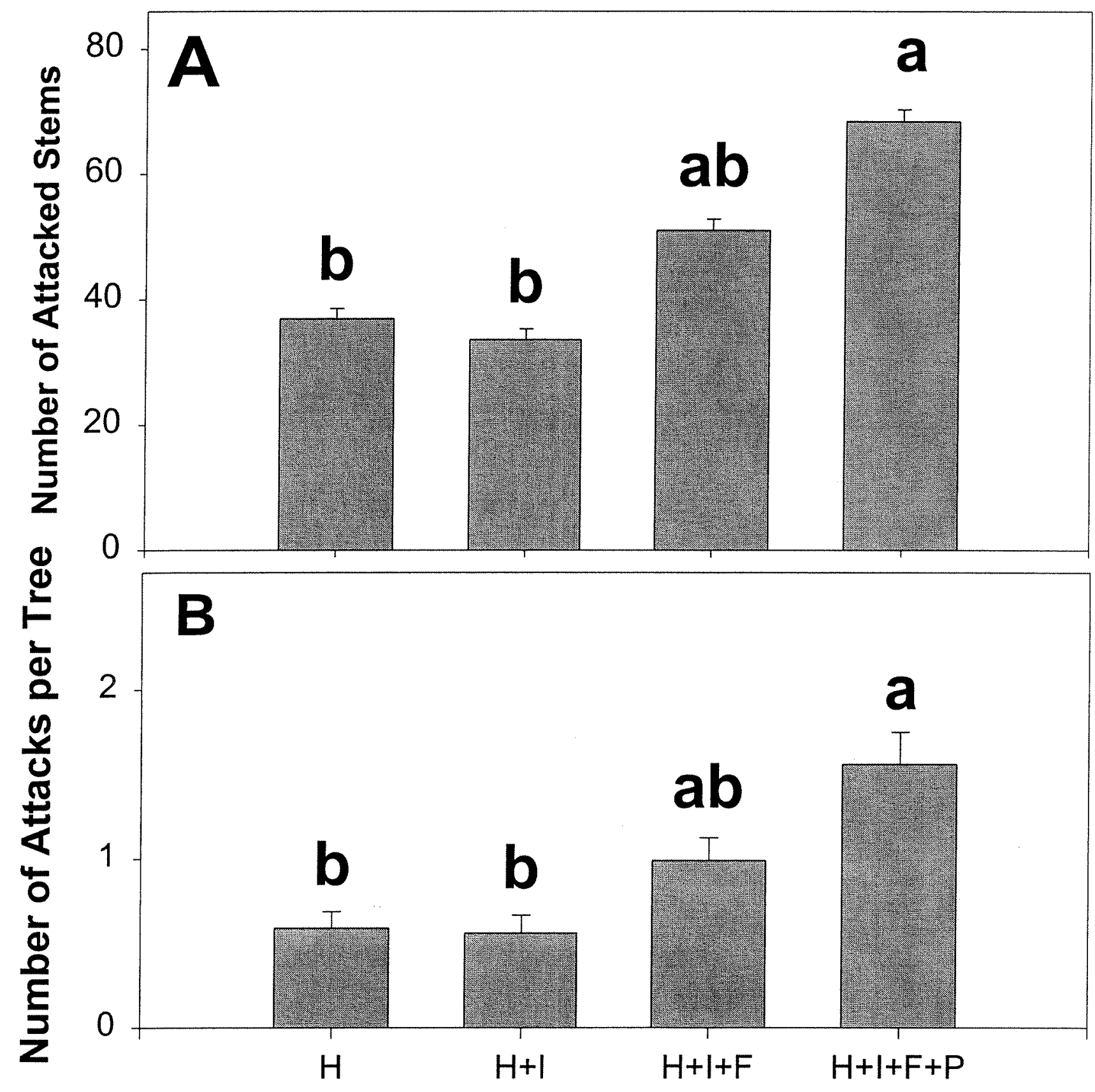




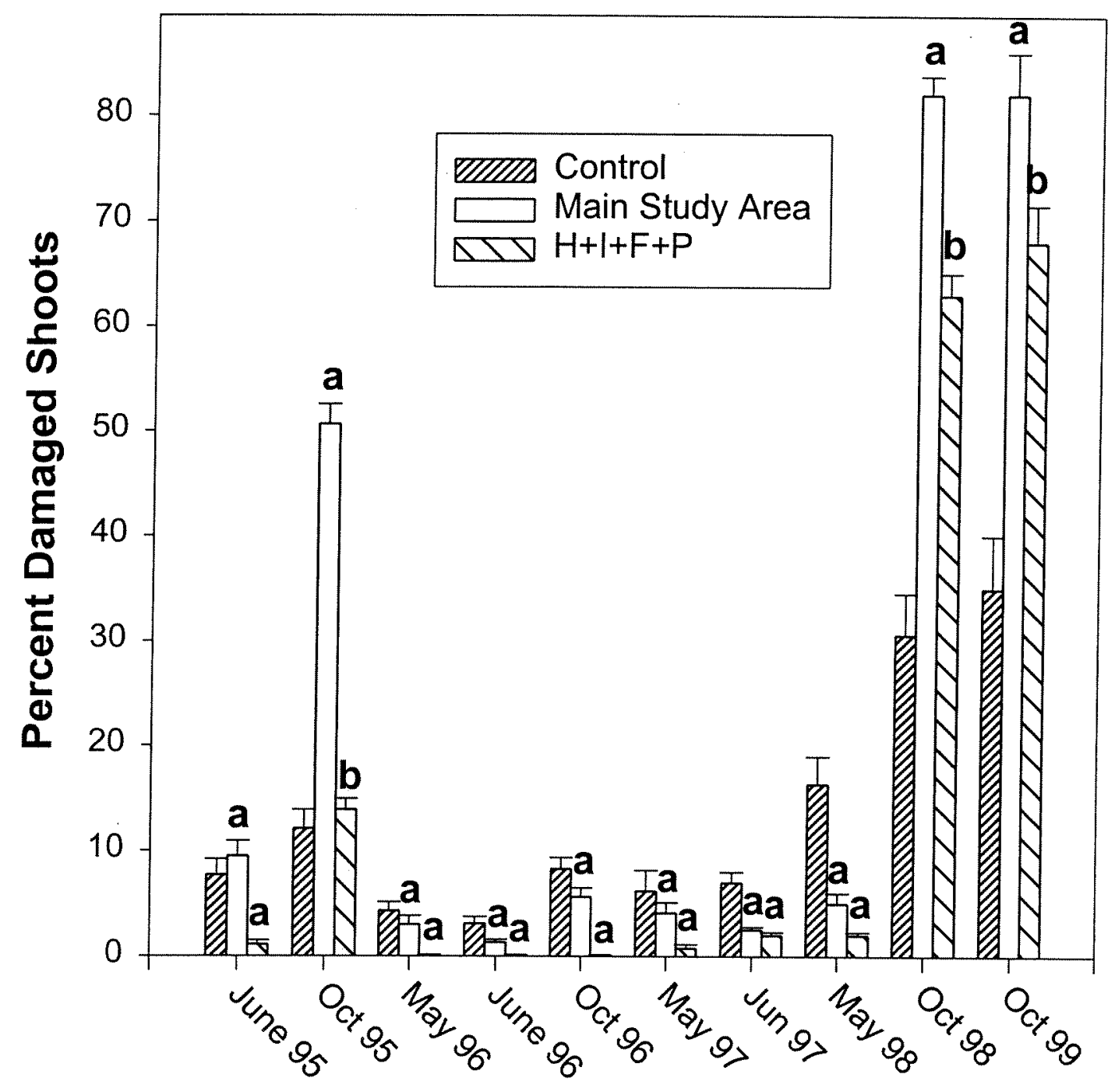




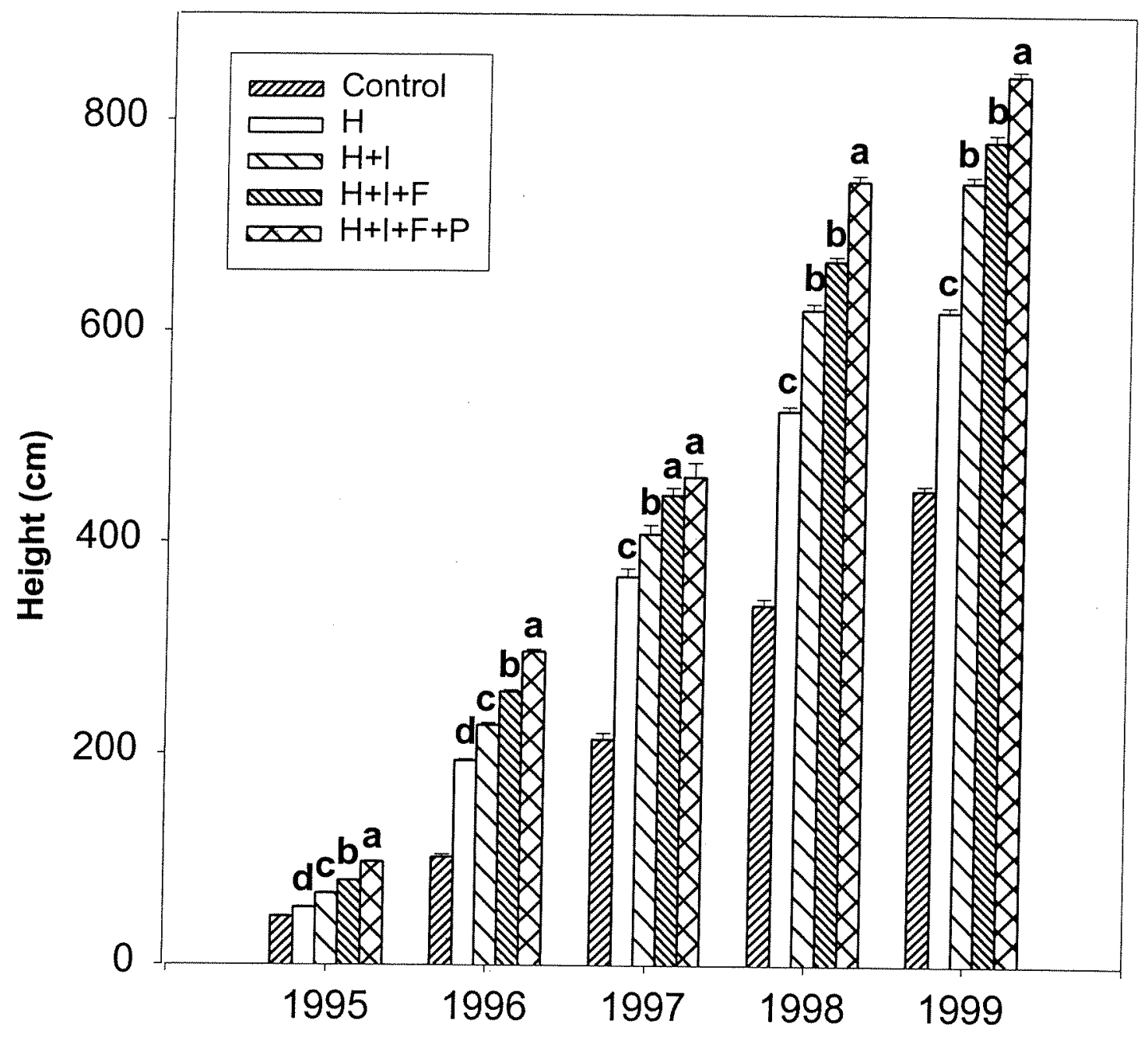




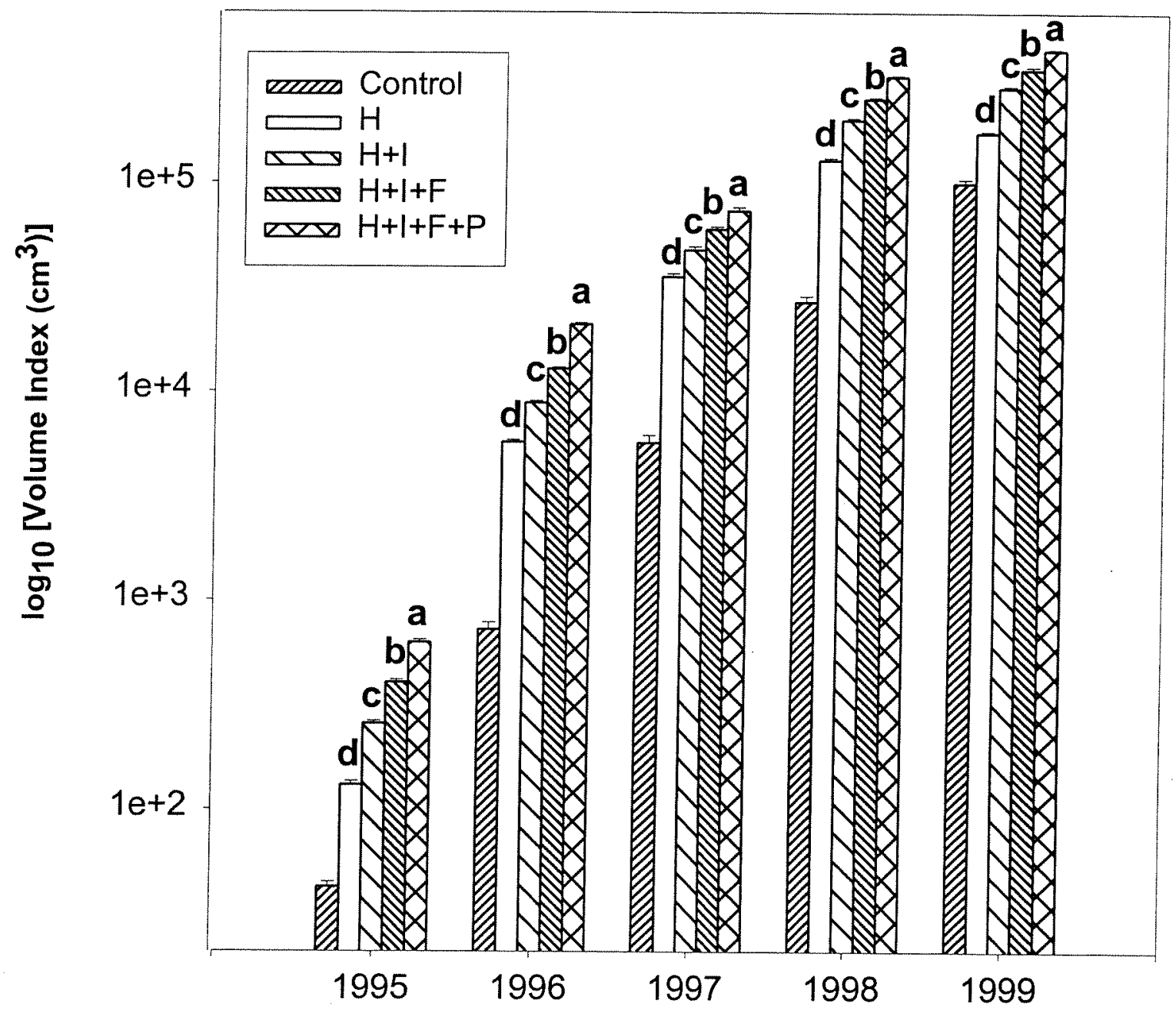

